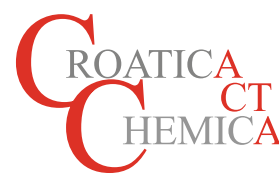

\title{
Some Microstructural Properties of Zinc Borosilicate Glass as a Possible Matrix in the Immobilization of Various Wastes
}

\author{
Svetozar Musić, ${ }^{1,2, *}$ Marijan Marciuš, ${ }^{1}$ Stjepko Krehula, ${ }^{1}$ Stanko Popović, ${ }^{2,3}$ \\ Ernő Kuzmann, ${ }^{4}$ Zoltán Homonnay ${ }^{4}$
}

\footnotetext{
1 Ruđer Bošković Institute, Bijenička cesta 54, HR-10000 Zagreb, Croatia

2 Croatian Academy of Sciences and Arts, Trg Nikole Šubića Zrinskog 11, HR-10000 Zagreb, Croatia

3 Department of Physics, Faculty of Science, University of Zagreb, Bijenička cesta 32, HR-10000 Zagreb, Croatia

${ }^{4}$ Institute of Chemistry, Eötvös Loránd University, Budapest, Hungary

* Corresponding author's e-mail address: music@irb.hr
}

RECEIVED: September 24, 2019 * REVISED: October 18, 2019 * ACCEPTED: October 20, 2019

\begin{abstract}
Zinc borosilicate glass with optimized chemical composition was synthesized and doped with 5 wt $\% \alpha-\mathrm{Fe}_{2} \mathrm{O}_{3}$. XRD, ${ }^{57} \mathrm{Fe}$ Mössbauer, FT-IR, UV/Vis/NIR and FE SEM were used as the characterization methods. XRD showed the amorphous nature of the samples synthesized. ${ }^{57}$ Fe Mössbauer spectra confirmed the superposition of $\mathrm{Fe}^{3+}$ in tetrahedral and $\mathrm{Fe}^{2+}$ in octahedral positions. FT-IR spectra showed general features characteristic of different borosilicate glasses. The NIR band at $1116 \mathrm{~nm}$ in the UV/Vis/NIR spectrum was assigned to the Fe ${ }^{2+}$ transition, whereas the $\mathrm{Fe}^{3+}$ transition bands could not be assigned due to the overlapping of several spectral bands of different origin in the UV region centered at $282 \mathrm{~nm}$ and the Vis region between 415 to $496 \mathrm{~nm}$. Zinc borosilicate glass as synthesized can be considered as a possible matrix in the immobilization of nonradioactive as well as radioactive wastes.
\end{abstract}

Keywords: zinc borosilicate glass, immobilization matrix, nonradioactive waste, radioactive waste, XRD, ${ }^{57}$ Fe Mössbauer, FT-IR, UV/Vis/NIR.

\section{INTRODUCTION}

V ARIOUS wastes (nonradioactive and radioactive) generated by man's activity are creating great problems in the contemporary world, and for this reason it is not surprising that many scientists and engineers are searching for the methods of their immobilization. Nonradioactive waste can be of different origins, for example, generated by the incineration of municipal, medical or biomass waste, the combustion of coal in thermal power plants as well as from slag in iron metallurgy, mud from metal in hydrometallurgy, etc. Glass and glass-ceramics have been considered for the immobilization of nonradioactive waste ${ }^{[1-5]}$ with further application as ceramics and construction materials. Radioactive waste can be produced in different steps of the nuclear fuel cycle or during the application of radioisotopes to other human activities. Glass-forming regions in the system $\mathrm{ZnO}-\mathrm{B}_{2} \mathrm{O}_{3}-\mathrm{SiO}_{2}{ }^{[6]}$ as well as the effects of the $\mathrm{ZnO}$ component in the borosilicate glass matrix on a possible immobilization of radioactive waste were investigated. [7-10]

In this paper we present some microstructural properties of zinc borosilicate glass with optimized chemical composition for a possible immobilization of nonradioactive or radioactive wastes.

\section{EXPERIMENTAL}

\section{Preparation of Glass Samples}

Zinc borosilicate glass was prepared using the commercial chemicals, $\mathrm{ZnO}, \mathrm{H}_{3} \mathrm{BO}_{3}, \mathrm{Na}_{2} \mathrm{CO}_{3}, \mathrm{~K}_{2} \mathrm{CO}_{3}, \mathrm{CaCO}_{3}, \mathrm{MgO}, \mathrm{SrCO}_{3}$ $\mathrm{BaCO}_{3}$, whereas amorphous $\mathrm{SiO}_{2}$ was prepared by Musić et al. ${ }^{[11]}$ The starting chemical composition (in wt \%) of zinc borosilicate glass in the form of oxide was the following: $28.8 \% \mathrm{ZnO}, 15.2 \% \mathrm{~B}_{2} \mathrm{O}_{3}, 37.0 \% \mathrm{SiO}_{2}, 5.5 \% \mathrm{Na}_{2} \mathrm{O}, 5.5 \% \mathrm{~K}_{2} \mathrm{O}$, 
$2.0 \% \mathrm{CaO}, 2.0 \% \mathrm{MgO}, 2.0 \% \mathrm{SrO}$ and $2.0 \% \mathrm{BaO}$. The iron component was added in the form of hematite (5 wt \% $\alpha-\mathrm{Fe}_{2} \mathrm{O}_{3}$ ) powder supplied by Ventron.

The corresponding amounts of the chemicals were mixed with a small amount of twice distilled water, then dried. After drying this mixture was ground, then melted in ceramic crucible in a laboratory furnace while gradually increasing temperature up to $1000{ }^{\circ} \mathrm{C}$ and kept at this temperature for $4 \mathrm{~h}$. In the case of the zinc borosilicate glass matrix loaded with $30 \mathrm{wt} \% \alpha-\mathrm{Fe}_{2} \mathrm{O}_{3}$ the system was additionally heated to $1100{ }^{\circ} \mathrm{C}$ for $1 \mathrm{~h}$. Molten glass was poured into a preheated graphite mould, then cooled to room temperature.

\section{Instrumentation}

XRD patterns were recorded at $20{ }^{\circ} \mathrm{C}$ with an APD 2000 diffractometer manufactured by ItalStructures (Novara, Italy).

Mössbauer spectra were recorded at 295 and $80 \mathrm{~K}$ in the transmission mode using the instrumentation by WisSEI (Starnberg, Germany). A ${ }^{57} \mathrm{Co} / \mathrm{Rh}$ Mössbauer source was used. The velocity scale and all Mössbauer data refer to the $\alpha$-Fe absorber at $295 \mathrm{~K}$. Mössbauer spectra were evaluated using the MossWinn program.

FT-IR spectra were recorded at RT using a PerkinElmer spectrometer (model Frontier).

UV/Vis/NIR spectra were recorded at RT using a UV3600 spectrometer manufactured by Shimadzu and equipped with an integrating sphere. Extra pure $\mathrm{BaSO}_{4}$ by Wako Chemicals was used as a reference.

FE SEM images were taken with a thermal field emission scanning electron microscope (model JSM 7000F) manufactured by JEOL Ltd.

\section{RESULTS AND DISCUSSION}

Figure 1. shows the XRD patterns of (a) zinc borosilicate glass, and (b) with 5 wt \% loading of $\alpha-\mathrm{Fe}_{2} \mathrm{O}_{3}$. These XRD patterns did not show any presence of a crystalline phase. Figure 2 shows the Mössbauer spectra of zinc borosilicate glass containing iron ions. These spectra, as recorded at 295 and $80 \mathrm{~K}$, indicate the superposition of two quadrupole doublets with Mössbauer parameters given in Table 1. The doublet with a greater quadrupole splitting can be assigned to $\mathrm{Fe}^{2+}$ ions in the octahedral environment, whereas the one with a lower quadrupole splitting can be assigned to $\mathrm{Fe}^{3+}$ ions in the tetrahedral environment. Cochain et al. ${ }^{[12]}$ reported about the state of iron in silicate glasses. In these glasses $\mathrm{Fe}^{2+}$ is present in octahedral and $\mathrm{Fe}^{3+}$ in tetrahedral coordination. A similar conclusion was reached by Taragin and Eisenstein ${ }^{[13]}$ for the state of iron in some borosilicate glasses. Romero et al. ${ }^{[14,15]}$ investigated the state of iron in borosilicate glasses of different chemical composition and

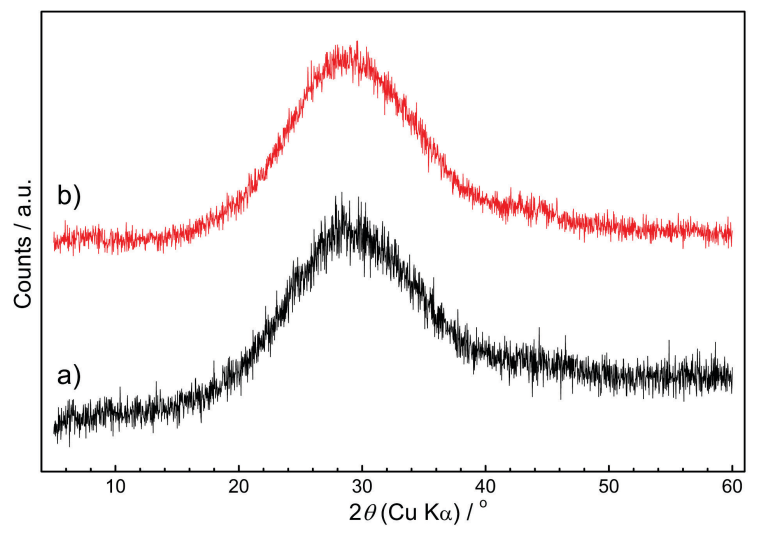

Figure 1. XRD patterns of (a) zinc borosilicate glass, and (b) with 5 wt \% loading of $\alpha-\mathrm{Fe}_{2} \mathrm{O}_{3}$.

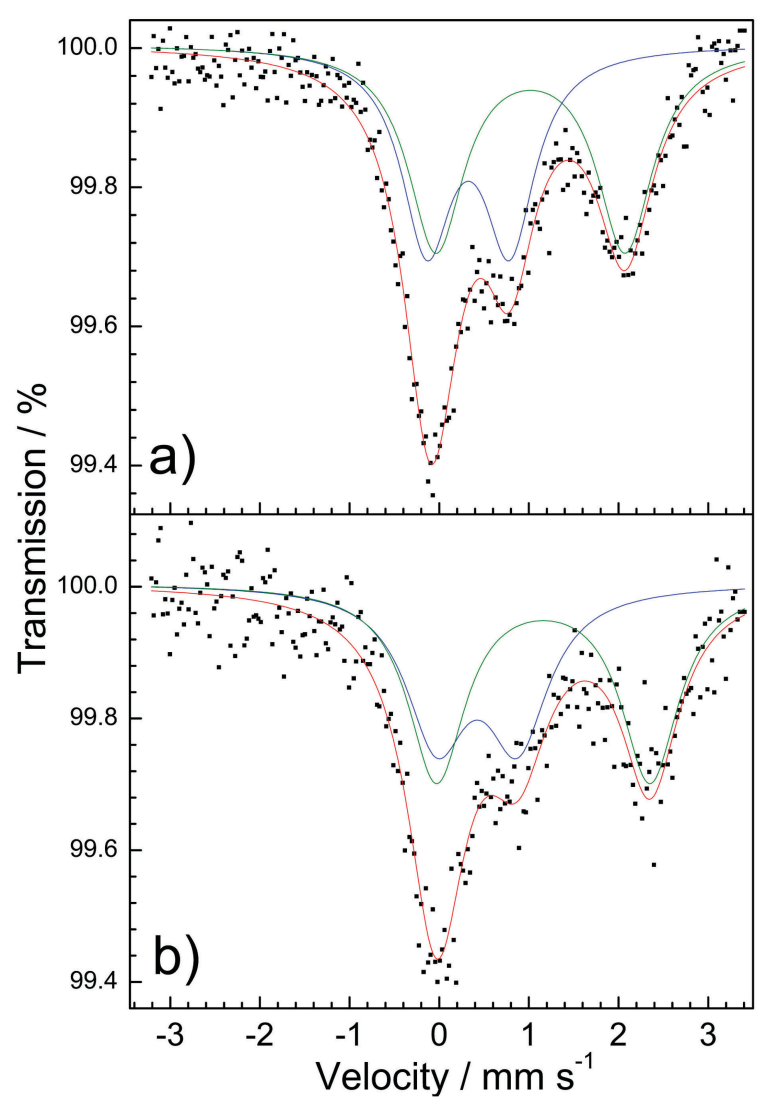

Figure 2. ${ }^{57} \mathrm{Fe}$ Mössbauer spectra of zinc borosilicate glass containing dissolved iron ions as recorded at (a) $295 \mathrm{~K}$ and (b) $80 \mathrm{~K}$.

found a dependence of the $\mathrm{Fe}^{3+} / \mathrm{Fe}^{2+}$ ratio on the $\mathrm{Fe}_{2} \mathrm{O}_{3}$ content as well as an increasing distortion of the glass network with the increased $\mathrm{Fe}_{2} \mathrm{O}_{3}$ content. Table 1 shows a significant broadening of quadrupole splitting lines which can be assigned to a wide distribution of iron at $\mathrm{Fe}^{2+}$ and $\mathrm{Fe}^{3+}$ sites in the amorphous glass matrix. Generally, it is 
Table 1. ${ }^{57} \mathrm{Fe}$ Mössbauer parameters of zinc borosilicate glass doped with 5 wt $\% \alpha-\mathrm{Fe}_{2} \mathrm{O}_{3}$.

\begin{tabular}{cccccc}
\hline Line & $\begin{array}{c}\delta / \\
\mathrm{mm} \mathrm{s}^{-1}\end{array}$ & $\begin{array}{c}\Delta / \\
\mathrm{mm} \mathrm{s}^{-1}\end{array}$ & $\begin{array}{c}\Gamma / \\
\mathrm{mm} \mathrm{s}^{-1}\end{array}$ & Area /\% & $T / \mathrm{K}$ \\
\hline $\mathrm{Q}_{1}$ & 0.32 & 0.92 & 0.68 & 46.3 & 295 \\
$\mathrm{Q}_{2}$ & 1.02 & 2.11 & 0.76 & 53.7 & 295 \\
$\mathrm{Q}_{1}$ & 0.42 & 0.90 & 0.83 & 45.0 & 80 \\
$\mathrm{Q}_{2}$ & 1.16 & 2.38 & 0.78 & 55.0 & 80 \\
\hline
\end{tabular}

Key: $\delta=$ isomer shift; $\Delta=$ quadrupole splitting; $\Gamma=$ line width Errors: $\delta= \pm 0.01 \mathrm{~mm} \mathrm{~s}^{-1} ; \Delta= \pm 0.01 \mathrm{~mm} \mathrm{~s}^{-1}$.

argued that the incorporation of iron ions in the borosilicate matrix reduces the boron coordination that is demonstrated by a decrease in the amount of $\mathrm{BO}_{4}$ tetrahedra and a corresponding increase in $\mathrm{BO}_{3}$ triangles. This is accompanied by the breaking of Si-O-B network bonds and the formation of $\mathrm{Si}-\mathrm{O}-\mathrm{Fe}^{3+}$ bridge bonds as well as $\mathrm{Si}-\mathrm{O}^{-}$nonbridging bonds including $\mathrm{Fe}^{2+}$ as modifying cations. ${ }^{[16,17]}$

The FT-IR spectra of (a) zinc borosilicate glass, and (b) with 5 wt \% loading of $\alpha-\mathrm{Fe}_{2} \mathrm{O}_{3}$ are shown in Figure 3 . General features of these spectra are typical of borosilicate glass. The weak IR band at $1738 \mathrm{~cm}^{-1}$ (Figure 3a) can be assigned to the ring asymmetric stretching relaxation of $\mathrm{B}-\mathrm{O}$ bonds in $\mathrm{BO}_{3}$ triangles. The IR band at $1370 \mathrm{~cm}^{-1}$ can be related to the ring stretching vibrations of $\mathrm{BO}_{3}$ whereas the IR band at $1248 \mathrm{~cm}^{-1}$ is usually interpreted as the bond stretching vibration of the boron sublattice against the oxygen sublattice. A very strong IR band centered at 967 $\mathrm{cm}^{-1}$ can be assigned to the stretching vibrations of $\mathrm{Si}-\mathrm{O}$ and $\mathrm{B}-\mathrm{O}$ bonds of tetrahedrally coordinated $\mathrm{Si}^{4+}$ and $\mathrm{B}^{3+}$. This IR band showed a very high broadening, thus indicating that there is a superposition of several IR bands. The IR band at 707 to $704 \mathrm{~cm}^{-1}$ can be related to the vibrations of the $\mathrm{B}-\mathrm{O}$ bond in $\mathrm{BO}_{3}$ triangle with an increased relative

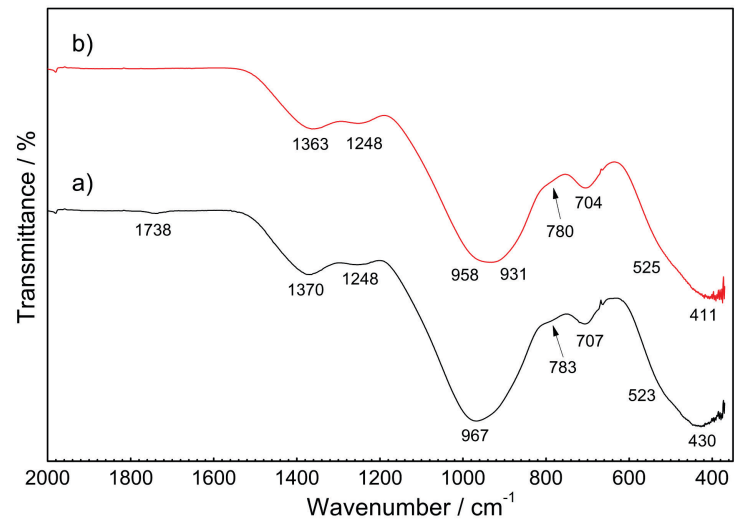

Figure 3. FT-IR spectra of (a) zinc borosilicate glass, and (b) ) with 5 wt \% loading of $\alpha-\mathrm{Fe}_{2} \mathrm{O}_{3}$. intensity of this band while increasing $\alpha-\mathrm{Fe}_{2} \mathrm{O}_{3}$ or waste loadings. Finally, a very strong and broadened IR band at $430 \mathrm{~cm}^{-1}$ was observed, which could be assigned to the bending vibrations within $\mathrm{SiO}_{4}$ tetrahedra (O-Si-O) and between $\mathrm{SiO}_{4}$ tetrahedra ( $\mathrm{Si}-\mathrm{O}-\mathrm{Si}$ ) as well as the $\mathrm{Zn}$ vibrations within $\mathrm{ZnO}_{6}$ octahedra and other $\mathrm{Me}-\mathrm{O}$ bonds ( $\mathrm{Me}-\mathrm{Mg}, \mathrm{Ca}, \mathrm{Sr}, \mathrm{Ba}$ ). The addition of $5 \mathrm{wt} \% \alpha-\mathrm{Fe}_{2} \mathrm{O}_{3}$ to the zinc borosilicate glass matrix did not significantly influence the corresponding FT-IR spectrum (Figure 3b). More about the interpretations of the borosilicate glass structure based on infrared spectroscopy can be found in reference literature. ${ }^{[18-22]}$

Figure 4. shows the UV/Vis/NIR spectra of (a) zinc borosilicate glass, and (b) with $5 \mathrm{wt} \%$ loading of $\alpha-\mathrm{Fe}_{2} \mathrm{O}_{3}$. Here it can be mentioned that the UV/Vis/NIR spectra of borosilicate glasses were much less investigated than the infrared spectra of the same glasses. Kukkadapu et al.[23] investigated sodium silicate glass doped with $0.5 \mathrm{~mol} \%$ $\mathrm{Fe}_{2} \mathrm{O}_{3}$. The broad bands at 1120 and $2020 \mathrm{~nm}$ were assigned to the $\mathrm{Fe}^{2+}$ transition, whereas the minor bands at 375,415 and $435 \mathrm{~nm}$ as well as the broad band at $\sim 485 \mathrm{~nm}$ were assigned to the $\mathrm{Fe}^{3+}$ transition. In the present UV/Vis/NIR spectrum (Figure 4.b) the band at $1116 \mathrm{~nm}$ is visible as a shoulder. Moreover, in the same spectral region two shoulders at 926 and $1288 \mathrm{~nm}$ are also visible. However, in the present case there are no great differences between the UV/Vis/NIR spectra of undoped and Fe-doped zinc borosilicate glasses. El Batal et al. ${ }^{[24]}$ investigated the UV/Vis spectra of TM-doped $\mathrm{Na}_{2} \mathrm{O}-\mathrm{B}_{2} \mathrm{O}_{3}-\mathrm{SiO}_{2}$ glasses (TM = transition metal). The spectrum of Fe-doped sodium borosilicate glass showed four prominent UV bands at 210, 235,275 and $315 \mathrm{~nm}$ as well as two weak bands at 380 and $440 \mathrm{~nm}$. The increase in relative intensity with progressive gamma irradiation was explained by the oxidation of $\mathrm{Fe}^{2+}$ and the formation of $\mathrm{Fe}^{3+}$. Bartoll et al. ${ }^{[25]}$ found a band at $300 \mathrm{~nm}$ in the UV/Vis spectrum of gamma irradiated Fedoped alkaline earth silicate glasses. In the present case Fe-

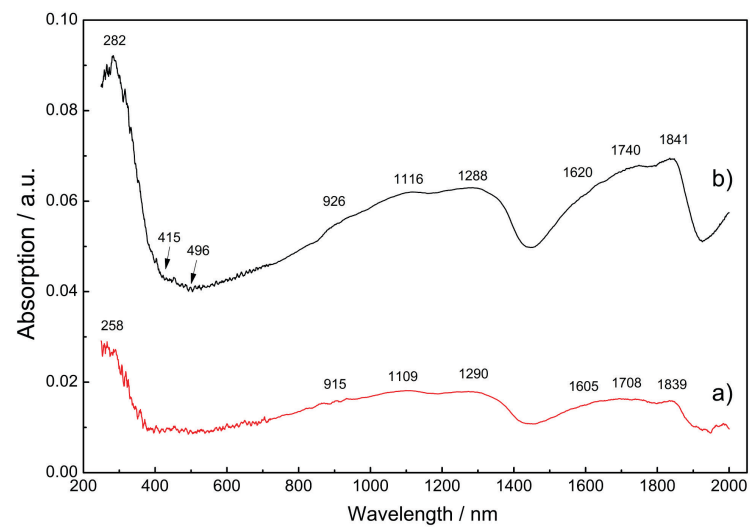

Figure 4. UV/Vis/NIR spectra of (a) zinc borosilicate glass, and (b) ) with $5 \mathrm{wt} \%$ loading of $\alpha-\mathrm{Fe}_{2} \mathrm{O}_{3}$. 




Figure 5. Zinc borosilicate glass fibers loaded with $5 \mathrm{wt} \%$ of $\alpha-\mathrm{Fe}_{2} \mathrm{O}_{3}$ as withdrawn from the melt.

doped zinc borosilicate glass showed a very strong and broad band centered at $282 \mathrm{~nm}$. A very weak shoulder at 415 to $496 \mathrm{~nm}$ was also visible due to the presence of $\mathrm{Fe}^{3+}$ ions.

The zinc borosilicate glass matrix as described has a high loading capacity for various wastes. However, when the waste loading was simulated with $30 \mathrm{wt} \% \alpha-\mathrm{Fe}_{2} \mathrm{O}_{3}$, the XRD pattern showed the crystallization of the spinel phase ( $10 \%)$ inside the glass matrix. Furthermore, glass fibers (or glass wool) can be produced by drawing out from molten zinc borosilicate glass. Figure 5 . shows glass fibers obtained from the zinc borosilicate glass matrix loaded with $5 \mathrm{wt} \% \alpha-\mathrm{Fe}_{2} \mathrm{O}_{3}$. In the case of nonradioactive waste, due to economic reasons, strontium can be replaced with cheaper alkaline earths.

\section{CONCLUSIONS}

Zinc borosilicate glass with optimized chemical composition was synthesized and showed a completely amorphous nature. Upon loading with 5 wt $\% \alpha-\mathrm{Fe}_{2} \mathrm{O}_{3}$ the Mössbauer spectra at 295 and $80 \mathrm{~K}$ showed a superposition of two quadrupole doublets corresponding to $\mathrm{Fe}^{3+}$ in tetrahedral positions and $\mathrm{Fe}^{2+}$ in octahedral positions. The ratio $\mathrm{Fe}^{3+} / \mathrm{Fe}^{2+}=0.86$ was measured at $295 \mathrm{~K}$ and a similar ratio was obtained at $80 \mathrm{~K}$. The FT-IR spectra showed the general features of the borosilicate glass matrix. In the UV/Vis/NIR spectrum the NIR band at $1116 \mathrm{~nm}$ was assigned to $\mathrm{Fe}^{2+}$ ions, whereas in the UV/Vis/NIR region the $\mathrm{Fe}^{3+}$ transitions were not well visible due to the overlapping of several UV bands centered at $282 \mathrm{~nm}$ and several Vis bands between 415 and $496 \mathrm{~nm}$. The zinc borosilicate glass matrix can be considered in the immobilization of nonradioactive or radioactive wastes.
Acknowledgment. The authors wish to thank Marijan Gotic for his assistance in the investigation of zinc borosilicate glass.

\section{REFERENCES}

[1] J. Ma. Rincón, M. Romero, A. R. Boccaccini, J. Mater. Sci. 1999, 34, 4413-4423.

https://doi.org/10.1023/A:1004620818001

[2] R. D. Rawlings, J. P. Wu, A. R. Boccaccini, J. Mater. Sci. 2006, 41, 733-761.

https://doi.org/10.1007/s10853-006-6554-3

[3] S. R. Teixeira, R. S. Magalhāes, A. Arenales, A. E. Souza, M. Romero, J. Ma. Rincón, J. Environ. Management, 2014, 134, 15-19.

https://doi.org/10.1016/j.jenvman.2013.12.029

[4] M. Romero, M. S. Hernández-Crespo, J. Ma. Rincón, Adv. Appl. Ceramics 2009, 108, 67-71.

https://doi.org/10.1179/174367608X366337

[5] S. Ballesteros, J. Ma. Rincón, B. Rincón-Mora, M. M. Jordán, J. Geochem. Exploration 2017, 174, 132-139. https://doi.org/10.1016/j.gexplo.2016.07.011

[6] E. H. Hamilton, R. M. Waxler, J. M. Nivert Jr., J. Res. Nat. Bureau Stand. 1959, 62, 59-62. https://doi.org/10.6028/jres.062.011

[7] D. E. Clark, E. L. Yen-Bower, L. L. Hench, Corrosion Behavior of Zinc Borosilicate Simulated Nuclear Waste Glass, Cearmics in Nuc. Waste Manage., Proc. of Int. Symp. Cincinnati, OH, 30 April-2 May 1979, 256-262.

[8] H. Zhang, C. L. Corkhill, P. G. Heath, R. J. Hand, M. C. Stennett, N. C. Hyatt, J. Nucl. Mater. 2015, 462, 321328. https://doi.org/10.1016/j.jnucmat.2015.04.016

[9] N. J. Cassingham, C. L. Corkhill, M. C. Stennett, R. J. Hand, N. C. Hyatt, J. Nucl. Mater. 2016, 479, 639-646. https://doi.org/10.1016/j.jnucmat.2016.06.009

[10] S. Musić, M. Gotić, S. Popović, B. Gržeta, J. Radioanal. Nucl. Chem. 1987, 116, 141-157. https://doi.org/10.1007/BF02037218

[11] S. Musić, N. Filipović-Vinceković, L. Sekovanić, Braz. J. Chem. Eng. 2011, 28, 89-94. https://doi.org/10.1590/S0104-66322011000100011

[12] B. Cochain, D. R. Neuville, G. S. Henderson, C. A. McCammon, O. Pinet, P. Richet, J. Am. Ceram. Soc. 2012, 95, 962-971.

[13] M. F. Taragin, J. C. Eisenstein, J. Non-Crystalline Solids 1970, 3, 311-316.

https://doi.org/10.1016/0022-3093(70)90001-3

[14] M. Romero, J. Ma. Rincón, S. Musić, V. Kozhukharov, Mater. Res. Bull. 1999, 34, 1107-1115. https://doi.org/10.1016/S0025-5408(99)00110-5

[15] M. Romero, J. Ma. Rincón, S. Musić, V. Kozhukharov, Revista de Metalurgia (Madrid), 1997, 33, 317-323. https://doi.org/10.3989/revmetalm.1997.v33.i5.844 
[16] V. E. Eremyashev, A. B. Mironov, Inorg. Mater. 2015, 51, 177-181.

https://doi.org/10.1134/S0020168515020065

[17] Y. S. Glazkova, S. N. Kalmykov, I. A. Presnyakov, O. I. Stefanovskaya, S. V. Stefanovsky, Glass Phys. Chem. 2015, 41, 367-377.

https://doi.org/10.1134/S1087659615040057

[18] A. S. Tenney, J. Wong, J. Chem. Phys. 1972, 56, 5516-5523.

https://doi.org/10.1063/1.1677069

[19] Y. Sun, Z. Zhang, Metall. Mater. Trans. B, 2015, 46, 1549-1554.

https://doi.org/10.1007/s11663-015-0374-2

[20] M. S. Meikhail, A. M. Abdelghany, Silicon, 2017, 9, 895900. https://doi.org/10.1007/s12633-016-9543-4
[21] H. Kamal, A. M. Hezma, Silicon, 2018, 10, 851-858. https://doi.org/10.1007/s12633-016-9540-7

[22] A. Madheshiya, K. K. Dey, M. Ghosh, J. Singh, C. Gautam, J. Non-Crystalline Solids 2019, 503-504, 288-296.

https://doi.org/10.1016/j.jnoncrysol.2018.10.009

[23] R. K. Kukkadapu, H. Li, G.L. Smith, J. D. Crum, J.-S. Jeoung, W. H. Poisl, M. C. Weinberg, J. NonCrystalline Solids 2003, 317, 301-318.

https://doi.org/10.1016/S0022-3093(02)01815-X

[24] F. H. El Batal, M. S. Selim, S. Y. Marzouk, M. A. Azooz, Physica B 2007, 398, 126-134.

https://doi.org/10.1016/j.physb.2007.05.004

[25] J. Bartoll, M. Nofz, R. Stösser, Phys. Chem. Glasses 2000, 41, 140-149. 